\title{
Students' Attitudes towards Group Collaborative Learning Experiences: A Case of University of Eastern Africa, Baraton
}

\author{
Lazarus Ndiku Makewa \\ School of Education, Department of Educational Administration \\ Curriculum and Teaching, University of Eastern Africa, Baraton,

\section{Mukami Dorcas} \\ School of Education, Department of Educational Administration \\ Curriculum and Teaching, University of Eastern Africa, Baraton,
}

\section{Ngussa Baraka}

School of Education, Department of Educational Administration Curriculum and Teaching, University of Eastern Africa, Baraton,

\section{Njoroge Samuel}

School of Education, Department of Educational Administration Curriculum and Teaching, University of Eastern Africa, Baraton,

\section{Kuboja Joshua}

School of Education, Department of Educational Administration Curriculum and Teaching, University of Eastern Africa, Baraton,

\begin{abstract}
This piece of work investigated students' attitudes towards group collaborative learning experiences and frustration. The study also sought to find out the relationship that existed between the student's gender, year of study, courses registered that semester, the number of hours dedicated to group collaborative learning per week with the students mean attitudes towards collaborative learning. The study established that most of respondents liked participating in collaborative working experiences, had great preference to work in collaboration with others, viewed collaborative learning experience as important except those in their second year of study who did not rate collaborative learning as very important, and tended to agree that they learned more in group than alone. It is therefore recommended that in the course of the lesson, teachers set time for group work to motivate the learners, not only interacting with the content, but also with the group members.
\end{abstract}

Keywords: Students, Attitudes, Group Collaborative, Learning Experiences, Frustrations

\section{INTRODUCTION}

The concept of collaborative learning, the grouping and pairing of students for the purpose of achieving an academic goal has been widely researched and advocated throughout the professional literature. Chambers Dictionary defines collaboration as to work in association with. It is the opposite of one working in isolation. The idea of collaborative learning is supported by Atkinson (1964) in Gillies, Ashman and Terwel (2007) who once said, "Achievement is a we thing, not a me thing, always the product of many heads and hands." 
Collaborative learning is described by Barkley, Cross and Major (2005) as learning activities expressly designed for and carried out through pairs or small interactive groups, working with one another or others, in pairs or small groups to achieve shared learning goals. It also means group working together rather than learning by working alone. It is the instructional use of the small groups so that students work together to maximize their own and each other's learning. Another term that can be used interchangeably with collaborative learning is cooperative learning though the two are not the same in operation.

According to Moore (2009), cooperative learning is more than simply putting students in groups but it requires that students work together in mixed-ability, gender and ethnicity groups in accomplishing a set of tasks. The percentage of high, middle or lower learners in each group should represent the appropriate population of each group in the whole class.

Kauchak and Eggen (2008) consider collaborative learning as a set of instructional strategies that is used to help learners meet specific learning and social interaction objectives in structured groups. Barkley, Cross and Major $(2005$, p. 4) give three features for effective collaborative learning:

- Intentional Design: The teacher must intentionally and not by chance group learners in a systematic way.

- Co-laboring: All participants in a group must engage actively in working together toward the stated objective.

- Meaningful learning: As students work together on collaborative assignments, they must increase their knowledge or deepen their understanding of the topic under discussion.

\section{Leadership and Size of Small Collaborative Groups}

Groups cannot succeed without leadership. Bergh and Theron (2006) support this when they argue that a working group is an unorganized mob. It must have a formal leader who can be identified with a varied range of titles such as manager, supervisor, foreman, project leader or head. They also maintain that this leader plays an important role in the group's success, and conclude that for high satisfaction in the group participative leadership is more effective than autocratic leadership. This idea suggests that a leader in class discussion groups should not dominate group activities but should give opportunity for each group member to give out their views and contributions. Furthermore, the leadership in the groups should be rotational so that many members in the group will have opportunity to develop leadership skills.

Significance of well sized groups for collaborative learning is indicated by Sharan et al., (1984); Sharan and Shachar, (1988) in Slavin $(2009$, p. 223) who have it that if students are well prepared to work in small groups and if the groups are well organized, students collaboration can increase students achievement more than traditional methods of learning. Johnson and Johnson in Slavin $(2009$, p. 223) further maintain that small group discussions have greater effects on students achievement if students are encouraged to engage in controversy rather than to seek a consensus. Gagne, Wager, Golas and Keller, 2005, p. 290) state that "a great deal of instruction is done with learners assembled in groups of various sizes."

The size of collaborative learning groups varies, depending on the task to be accomplished, but the common group size tends to be four (Moore, 2009). Slavin (2009, p.222) argues that "in small group discussion, students should work in four-to-six members to discuss a particular topic." 


\section{Unity and Dynamics in Small Groups}

Small groups are formed by people of different personalities, backgrounds, attitudes, culture and behavior. Amid all these dynamic differences, the target is to ensure togetherness, which can be brought by common interests. Togetherness is an important ingredient for the success of collaborative learning experiences.

Rue and Byars (1993) support this when they argue that once groups have been formed, they seem to take on a life of their own and over time, they develop certain characteristics and a set way of doing things. This is what is referred to by Bergh and Theron (2006) as group normsstandard of behavior that are shared by the group members and that provide guidance about what to do or not to do in certain circumstances. They further argue that when agreed and accepted by the group, norms act as means of influencing the behavior of group members with a minimum of external controls.

In the context of collaborative learning groups, a teacher needs to encourage every group to set a varied range of norms which do not contradict with school culture. This is also supported by Moore (2009, p. 203) who argues that team members should be allowed a great deal of freedom as they decide how to deal with the assigned task.

Rue and Byars (1993) and Fincham and Rhodes (2005) also argue that group norms are important sources of unity in the groups. They refer to group norm as an understanding among group members concerning how members should behave.

\section{Motivation in Group Collaborative Learning}

Group works cannot be effective without motivation. The teacher is the chief supervisor of class groups. He is one of the sources for motivation in the group. He needs to encourage and motivate each member of the groups to actively participate in group activities. Rue and Byars (1993) brings to view roles of supervisors of groups at work. He argues that the supervisor needs to consciously encourage members to participate in group activities, interact well with group members and have high performance goals. It is therefore the responsibility of the teacher to build these qualities among group members.

Besides, group members' individual accountability and personal responsibility are important ingredients for motivation (Moore, 2009and Gillies, Ashman and Terwel (2007). This is supported by Moore (2009, p. 203) who has it that "individual accountability is an essential characteristic of all cooperative learning. He suggests that accountability means that the success of the group is based on the individual learning of each team member. Accountability occurs when each student in the group is held responsible for the required learning goals."

This is supported by Gillies et al. (2007, p. 22) who maintain that positive interdependence creates responsibility forces that increase group members' feeling of responsibility and accountability for completing one's share of the work and facilitating the work of other group members. They cite Matsui et al. (1987) who argues that when person's performance affects the outcomes of collaborators, the person feels responsible for their welfare as well as his own. Thus, the shared responsibility created by positive interdependence adds the concept of "ought to" to group members' motivation. They conclude that "such feelings of responsibility increase a person's motivation to perform well." 


\section{THEORETICAL FRAMEWORK}

"Coming together is a beginning. Keeping together is progress. Working together is success." (Henry Ford, the former President of America).

One of the most important principles of educational psychology is recognizing the fact that knowledge can only be constructed through one's mind and through social interactions. This study is grounded on Lev Vygotsky's theory of social interaction and learning, and constructivist theoretical framework which advocates for learners being guided by the teachers in self-discovery experiences that yields effective learning.

Social learning theory help us to understand how people learn in social contexts (learn from each other) and informs us on how teachers, construct active learning communities. Vygotsky (1962) examined how our social environments influence the learning process. He suggested that learning takes place through the interactions students have with their peers, teachers, and other experts. Consequently, teachers can create a learning environment that maximizes the learner's ability to interact with each other through discussion, collaboration, and feedback.

Constructivism theory, on the other hand, believes on the ideas that learners must individually discover and transform complex information if they are to make it their own (Slavin, 2009 p.231). This view has profound implications for teaching because it suggests a far more active role for students in their own learning than is typical in many classrooms. Because of the emphasis on students as active participants, constructivist strategies are often called studentcentered instructions. The role of the teacher in this view as observed by Weinberger and McCombs (2001) is to guide students to discover their own meaning instead of lecturing and controlling all classroom activities.

A study by Geen and Gredler (2002, p. 54) comments further that when students are left alone with minimum supervision but with goal centered accomplishments, they can generate knowledge by constructing their own models of learning and hence keep the body of knowledge alive. Bruning, Schraw, Norby and Ronning (2004), have developed a number of different perspectives to constructivism theory showing how better the approaches can help improve learning. The conceptual framework (figure 1) illustrates the essence of engaging students in interaction through Group Collaborative Learning (GCL).

It is reemphasized that all of the above perspectives share the common assumption that knowledge must be constructed to be meaningful and can only be achieved through active involvement of the learner who not come in contact with the teacher tabulae rasae.

It is through this theory of constructivism, terms such as cooperative learning, discovery learning, collaborative learning, and team learning originate from. However, collaboration entails many components such as students teaching one another, students teaching the teacher, and the teacher teaching the students. More importantly, it means that students are responsible for one another's learning as well as their own and that reaching the goal implies that students have helped to understand and learn each other's experiences. Conclusively, when students are fundamentally exposed to such extensive use of methodologies, they will more easily discover and comprehend difficult concepts if they can talk to one other on a horizontal level (Pontecorvo, 1993). 


\section{METHOD}

This study employed a descriptive survey design (cross sectional survey). Students from the school of Education were the target population. Stratification sampling technique was used to get the specific students from each year. The undergraduate Education students in first, second, third and fourth years formed the strata for this study. For each of the strata, cards with 'Yes' and 'No' were generated and put in baskets. Each basket had fifteen cards with 'Yes' and the rest of the Cards were 'No'. To draw a representative sample of students, the researcher made use of simple random sampling procedure in that, those who picked 'Yes' filled the questionnaire which was the only means of data collection. In this way, each student had equal chance of being selected. The researchers came up with 60 students as representative sample, which is $33 \%$ of all Bachelors of Education students. Questionnaires were used to collected data. A pilot study was done to validate the reliability of the instruments.

\section{RESULTS AND DISCUSSION}

The following four point Scale was used to determine the respondents rating of the components in the questionnaire: $1=$ Disagree $2=$ Tend to Disagree $3=$ Tend to Agree and 4=Agree. Respondents circled the appropriate numbers to indicate their perception in different items. The respondent groups were interpreted as follows:

$$
\begin{aligned}
& 1.00-1.49=\text { Disagree } \\
& 1.50-2.49=\text { Tend to Disagree } \\
& 2.50-3.49=\text { Tend to Agree } \text { and } \\
& 3.50-4.00=\text { Agree }
\end{aligned}
$$

\begin{tabular}{|c|c|c|c|}
\hline Sample & Categories & $\begin{array}{l}\text { No. of } \\
\text { Respondents }\end{array}$ & Average \\
\hline \multirow[t]{2}{*}{ Gender } & Male & 23 & 3.39 \\
\hline & Female & 28 & 3.36 \\
\hline \multirow[t]{9}{*}{ Age } & 16-18 years & 4 & 3.25 \\
\hline & 19-21 years & 12 & 3.42 \\
\hline & 22-24 years & 11 & 3.45 \\
\hline & $25-27$ years & 16 & 3.31 \\
\hline & $28-30$ years & 2 & 2.50 \\
\hline & $31 \&$ above & 6 & 3.67 \\
\hline & First & 10 & 3.50 \\
\hline & Second & 14 & 3.07 \\
\hline & Third & 11 & 3.55 \\
\hline Year of study & Fourth & 16 & 3.44 \\
\hline \multirow{3}{*}{$\begin{array}{l}\text { Courses registered } \\
\text { for this semester }\end{array}$} & Two & 5 & 3.40 \\
\hline & Three & 4 & 2.75 \\
\hline & Four & 42 & 3.43 \\
\hline Hours per week & $1-5$ hours & 41 & 3.24 \\
\hline dedicated to group & $6-10$ hours & 4 & 3.75 \\
\hline collaborative & $11-15$ hours & 5 & 4.00 \\
\hline learning course & 16 or more & 1 & 4.00 \\
\hline
\end{tabular}

Table 1: Respondents' Rating on their attitude towards participation in group Collaborative learning experiences 
Table 1 indicates that respondents generally accepted that they liked to participate in group collaborative learning experiences. Categorically, those of 31 and above years, first years, third years and those who dedicated at least eleven hours in group collaborative learning experiences showed stronger acceptance than their counterparts. This indicates that the attitude of respondents, regardless of their varying characteristics, is generally positive towards collaborative learning experiences.

\begin{tabular}{|c|c|c|c|}
\hline Sample & Categories & $\begin{array}{lr}\text { No. of } \\
\text { Respondents } \\
\end{array}$ & Average \\
\hline \multirow[t]{2}{*}{ Gender } & Male & 23 & 1.87 \\
\hline & Female & 28 & 2.18 \\
\hline \multirow[t]{7}{*}{ Age } & 16-18 years & 4 & 1.75 \\
\hline & 19-21 years & 12 & 2.25 \\
\hline & $22-24$ years & 11 & 2.18 \\
\hline & $25-27$ years & 16 & 1.87 \\
\hline & 28-30 years & 2 & 4.00 \\
\hline & $31 \&$ above & 6 & 1.33 \\
\hline & First & 10 & 1.50 \\
\hline \multirow{3}{*}{ Year of study } & Second & 14 & 2.50 \\
\hline & Third & 11 & 2.00 \\
\hline & Fourth & 16 & 2.00 \\
\hline Courses registered & Two & 5 & 2.00 \\
\hline \multirow{2}{*}{ for this semester } & Three & 4 & 3.25 \\
\hline & Four & 42 & 1.93 \\
\hline Hours per week & $1-5$ hours & 41 & 2.24 \\
\hline dedicated to group & $6-10$ hours & 4 & 1.00 \\
\hline collaborative & $11-15$ hours & 5 & 1.00 \\
\hline learning course & 16 or more & 1 & 3.00 \\
\hline
\end{tabular}

It is quite evident from Table 2 that most of participants in different categories did not prefer doing collaborative learning activities alone. This implies that most of the students have great preference to work in collaboration with others in the groups. Those few who indicated preference to work alone are in the age bracket of 28-30. This is probably because of their commitment in their places of work or in their families. In addition, those in their second year of study, those who registered for three courses and those who dedicated 16 or more hours in collaborative experiences also tended to prefer working alone, but in a comparative sense, these categories had fewer respondents than their counterparts.

As shown in Table 3, respondents generally viewed activities carried out in collaborative learning experiences as important. Categorically, most of respondents strongly viewed the activities as important except those in their second year of study who comparatively viewed the activities important but in a lesser degree of importance. In relation to the importance of collaboration, Johnson and Johnson (1991) have emphasized the importance of positive interdependence, which occurs when students can only complete a task by working together; the task cannot be completed as effectively or at all when working individually. Effective positive interdependence is likely to result in joint attention to the tasks at hand (Barron, 2003). This means that there is no way a task that is supposed to be done collaboratively can be done otherwise hence echoing the importance of collaborative learning and especially in the contemporary classes where learning is learner centered. 
Table 3: Respondents' ratings on the importance of activities carried out in group collaboration in their learning.

\begin{tabular}{|c|c|c|c|}
\hline Sample & Categories & $\begin{array}{l}\text { No. of } \\
\text { Respondents } \\
\end{array}$ & Average \\
\hline \multirow[t]{2}{*}{ Gender } & Male & 23 & 3.52 \\
\hline & Female & 28 & 3.32 \\
\hline \multirow[t]{7}{*}{ Age } & 16-18 years & 4 & 3.25 \\
\hline & 19-21 years & 12 & 3.08 \\
\hline & $22-24$ years & 11 & 3.55 \\
\hline & $25-27$ years & 16 & 3.44 \\
\hline & $28-30$ years & 2 & 3.50 \\
\hline & $31 \&$ above & 6 & 3.83 \\
\hline & First & 10 & 3.60 \\
\hline \multirow{3}{*}{ Year of study } & Second & 14 & 2.93 \\
\hline & Third & 11 & 3.64 \\
\hline & Fourth & 16 & 3.56 \\
\hline \multirow{3}{*}{$\begin{array}{l}\text { Courses registered } \\
\text { for this semester }\end{array}$} & Two & 23 & 3.40 \\
\hline & Three & 28 & 3.50 \\
\hline & Four & 4 & 3.40 \\
\hline Hours per week & $1-5$ hours & 12 & 3.34 \\
\hline dedicated to group & $6-10$ hours & 11 & 3.50 \\
\hline collaborative & $11-15$ hours & 16 & 3.80 \\
\hline learning course & 16 or more & 2 & 4.00 \\
\hline
\end{tabular}

Table 4: Respondents' ratings on whether they learnt more working in groups than alone

\begin{tabular}{|c|c|c|c|}
\hline Sample & Categories & $\begin{array}{l}\text { No. of } \\
\text { Respondents }\end{array}$ & Average \\
\hline \multirow[t]{2}{*}{ Gender } & Male & 23 & 3.17 \\
\hline & Female & 28 & 3.00 \\
\hline \multirow[t]{7}{*}{ Age } & 16-18 years & 4 & 3.25 \\
\hline & 19-21 years & 12 & 2.92 \\
\hline & $22-24$ years & 11 & 2.82 \\
\hline & $25-27$ years & 16 & 3.13 \\
\hline & $28-30$ years & 2 & 2.50 \\
\hline & $31 \&$ above & 6 & 3.83 \\
\hline & First & 10 & 3.30 \\
\hline \multirow{3}{*}{ Year of study } & Second & 14 & 2.43 \\
\hline & Third & 11 & 3.27 \\
\hline & Fourth & 16 & 3.38 \\
\hline Courses registered & Two & 5 & 3.20 \\
\hline \multirow[t]{2}{*}{ for this semester } & Three & 4 & 2.75 \\
\hline & Four & 42 & 3.10 \\
\hline Hours per week & $1-5$ hours & 41 & 2.90 \\
\hline dedicated to group & $6-10$ hours & 4 & 3.50 \\
\hline collaborative & $11-15$ hours & 5 & 4.00 \\
\hline learning course & 16 or more & 1 & 4.00 \\
\hline
\end{tabular}

Majority of respondents in different categories, as shown in Table 4 agreed or tended to agree that they learnt more in groups than alone. This observation could be informed by the fact that 
in group learning, different individuals are talented differently. This helps all involved in the group to benefit from each other's contributions as they discuss. Those in their second year of studies, however, disagreed that they learn more working in groups than alone.

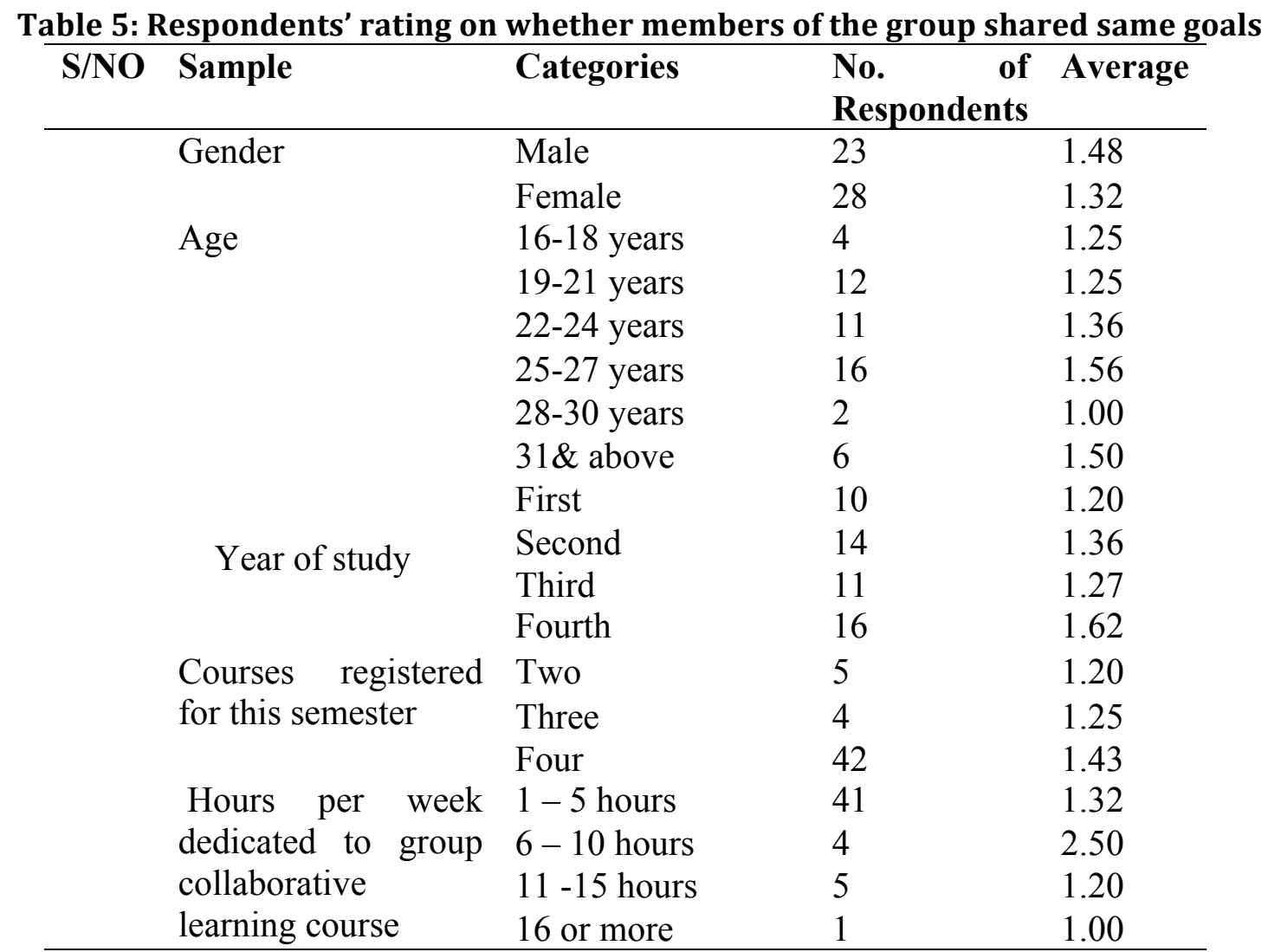

As shown in Table 5, there was a consensus among the participants in different categories of respondents that not all group members shared the same goals in the process of collaborative learning. Some common obstacles to achieving common goals among group participants are discussed by O'Donnell and O'Kelly (1994) and Salomon and Globerson (1989). First, wastage of time in off-task behavior. Secondly, students engagement in social loafing, in which some of them do little or none of the common work, relying instead on others to do the work for them. Third, unequal interactions, in which some students talk most of the time, and/or some students participate very little or not at all. Fourth, negative interactions among students (e.g., criticism, ridicule, or harassment). All these are causatives for lack of common goals among group members. .

In Table 6, the participants' responses indicate variation of responses about organization and distribution of tasks and responsibilities among group members. Particularly, majority tended to agree that it is easy to organize collaborative learning. This could be informed by the fact that in most academic group work initiated by the instructor, the first agenda is normally to constitute the officials of the group who include the chairperson, secretary and the time keeper. It is only two sub samples who view this task as not being easy. On the contrary, the females, the third years, and those who dedicate at least 11 hours for collaborative experiences tended to disagree that it is easy to organize collaborative learning. 
Table 6: Respondent's rating of the organization and distribution of tasks and Responsibilities among group members

\begin{tabular}{|c|c|c|c|}
\hline Sample & Categories & $\begin{array}{l}\text { No. of } \\
\text { Respondents }\end{array}$ & Average \\
\hline \multirow[t]{2}{*}{ Gender } & Male & 23 & 3.00 \\
\hline & Female & 28 & 2.21 \\
\hline \multirow[t]{7}{*}{ Age } & 16-18 years & 4 & 2.00 \\
\hline & 19-21 years & 12 & 2.75 \\
\hline & $22-24$ years & 11 & 2.55 \\
\hline & $25-27$ years & 16 & 2.81 \\
\hline & $28-30$ years & 2 & 1.50 \\
\hline & $31 \&$ above & 6 & 2.33 \\
\hline & First & 10 & 2.70 \\
\hline \multirow{3}{*}{ Year of study } & Second & 14 & 2.57 \\
\hline & Third & 11 & 1.64 \\
\hline & Fourth & 16 & 3.13 \\
\hline \multirow{3}{*}{$\begin{array}{l}\text { Courses registered } \\
\text { for this semester }\end{array}$} & Two & 5 & 2.60 \\
\hline & Three & 4 & 1.50 \\
\hline & Four & 42 & 2.67 \\
\hline Hours per week & $1-5$ hours & 41 & 2.51 \\
\hline dedicated to group & $6-10$ hours & 4 & 3.75 \\
\hline collaborative & $11-15$ hours & 5 & 2.40 \\
\hline learning course & 16 or more & 1 & 1.00 \\
\hline
\end{tabular}

Table 7: Respondents' ratings of their being in commode with the group members taking active roles

\begin{tabular}{|c|c|c|c|c|}
\hline S/NO & Sample & Categories & $\begin{array}{l}\text { No. of } \\
\text { Respondents }\end{array}$ & Average \\
\hline \multirow{2}{*}{\multicolumn{2}{|c|}{ Gender }} & Male & 23 & 2.00 \\
\hline & & Female & 28 & 1.89 \\
\hline \multirow{7}{*}{\multicolumn{2}{|c|}{ Age }} & $16-18$ years & 4 & 1.00 \\
\hline & & $19-21$ years & 12 & 2.17 \\
\hline & & $22-24$ years & 11 & 2.00 \\
\hline & & $25-27$ years & 16 & 1.88 \\
\hline & & $28-30$ years & 2 & 3.50 \\
\hline & & $31 \&$ above & 6 & 1.67 \\
\hline & & First & 10 & 1.70 \\
\hline \multirow{3}{*}{\multicolumn{2}{|c|}{ Year of study }} & Second & 14 & 2.00 \\
\hline & & Third & 11 & 1.82 \\
\hline & & Fourth & 16 & 2.13 \\
\hline & Courses registered & Two & 5 & 3.40 \\
\hline & for this semester & Three & 4 & 3.50 \\
\hline & & Four & 42 & 3.14 \\
\hline & Hours per week & $1-5$ hours & 41 & 1.90 \\
\hline & dedicated to group & $6-10$ hours & 4 & 2.50 \\
\hline & collaborative & $11-15$ hours & 5 & 2.00 \\
\hline & learning course & 16 or more & 1 & 1.00 \\
\hline
\end{tabular}


Table 7 indicates mixed responses in regard to being in commode with group members, taking active role. Most categories of respondents tended to disagree while a few (such as those between 28 and 30) agreed that they feel uncomfortable with group members taking active roles. It is interesting to note that comparatively, the categories of those that dedicates more than 11 hours per week and those is in the age group of 16-18 disagreed that they feel uncomfortable with group members taking active roles.

Table 8: Respondents" ratings of their feeling whether they are not bothered when other members work more than themselves

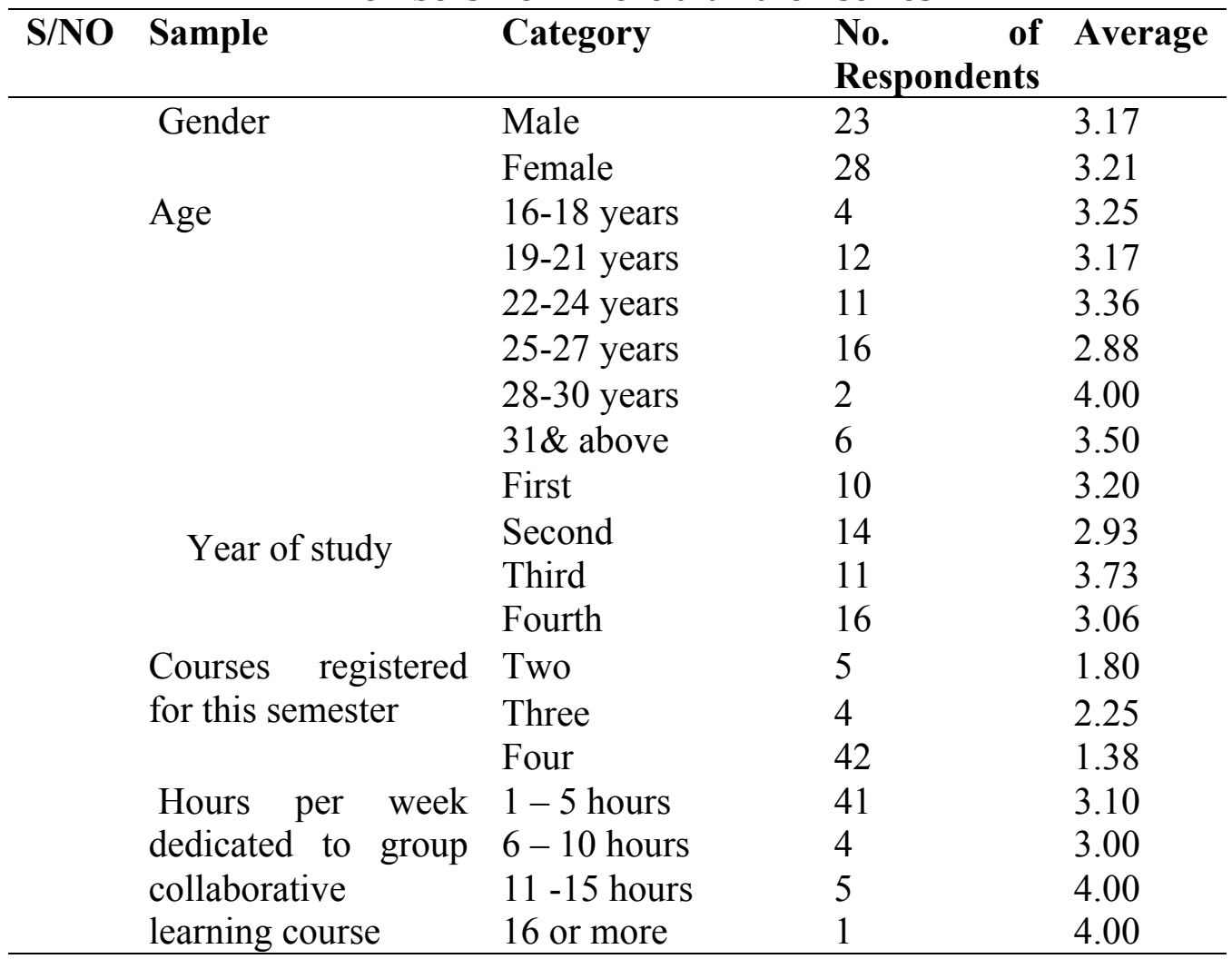

As indicated in Table 8, majority of participants in different categories agreed that it does not bother them when some members work more than them. Those who had registered for two courses and those who had registered for four courses, however, disagreed and showed that it bothered them when some members worked more than them. This could perhaps be due to the fact that there are some in the group who tend to dominate everything without allowing others to share their experiences. The major intention of collaborative learning is to create a situation where all the participants are able to discuss and contribute what they know to the groups. This means each individual is given an opportunity to showcase their academic prowess. However, there are still some who will work more than others in the group.

\section{DISCUSSION}

Learners in collaborative groups experience a wide range of positive and negative perceptions and emotions that influence their attitude towards group learning (Wissel, 2008).These perceptions and emotions are influenced by dynamics and interaction skills within a given group. Findings in this study are in consistence with those of Brownstein (2001) and Dayal (2007) who posited that collaborative learning approaches that are learner-centered with the teacher as a guide and facilitator enhances longer retention of learned concepts regardless of age or gender of group members. Such strategies develop higher order thinking, disciplinary knowledge base and practical skills by placing the learner in the active role of problem solver. 
The findings are also in harmony with that of Adolphus, Alamina and Aderonmu (2013) on effects of Collaborative Learning on problem solving abilities, which found no significant difference between the boys and girls. Therefore, as argued by Rue and Byars (1993), teachers as immediate supervisor of instruction need to consciously encourage members of different characteristics to form and actively participate in group collaborative activities and interact well with group members of opposite characteristics in order to reach high performance goal.

The results, however, disagree with the findings of Onah and Ugwu (2010) who indicated that performance in certain subjects, especially sciences in Secondary School level, is dependent on gender. It is also against the findings of Pinto (2012) whose investigation on the efficacy of homogeneous groups in enhancing individual learning revealed a significant improvement in individual student performance in the year the groups were made homogenous.

With these regards, therefore, it is advised that teachers should be creative enough to construct both heterogeneous and homogeneous collaborative groups of learners in order for learners to go through variety of learning experiences in order to affect effective learning.

\section{CONCLUSIONS AND RECOMMENDATIONS}

This work investigated students' attitudes towards group collaborative learning experiences. The results show that students liked participating in collaborative working experiences, had great preference to work in collaboration with others, viewed collaborative learning experience as important, and tended to agree that they learned more in group than alone. Although group members did not share the same goals in the process of collaborative learning, they tended to agree that it was easy to organize collaborative learning experiences.

Based on findings of this study, the following recommendations are suggested:

1. In the course of the lessons, teachers should set time for group work to motivate the learners not only to interact with the content, but also with the group members.

2. Since varying characteristics of learners do not influence their attitudes towards collaborative learning, teachers should organize groups of varying heterogeneous characteristics such as gender and age for effective collaborative learning so that learners will taste different types of experiences from their counterparts.

3. Since collaborative learning experiences are somehow frustrating in nature, teachers should be creative enough to motivate students and create joyful moments in collaborative learning so that learners will desire to participate in their groups amid frustration moments.

4. Teachers also need to train learners to work together in a mutual relationship considering the group dynamics principles.

Future studies need to investigate:

\section{AREAS FOR FURTHER STUDY}

1. Effective ways on assessing and evaluating group collaborative learning.

2. Psychological and Sociological management of frustration in group collaborative learning.

\section{References}

Adolphus, T; Alamina, A. and Aderonmu, A (2013). The Effects of Collaborative Learning Barkley, E. F., Cross, K. P \& Major, C. H (2005). Collaborative learning techniques. United Barron (2003)

Barron, B. (2003). When smart groups fail. The Journal of the Learning Sciences, 12(3), 307-359. 
Makewa, L. N., Dorcas, M., Baraka, N., Samuel, N., \& Joshua, K. (2015). Students' Attitudes towards Group Collaborative Lerning Experiences: A Case of University of Eastern Africa, Baraton. Advances in Social Sciences Research Journal, 2(8) 01-12.

Bergh, Z \& Theron, A (editors). Psychology in the work context. Cape Town: Oxford University

Brownstein, B (2001). Collaboration: “The foundation of learning in the future,” Education

Bruning, R. H; Schraw, G. J; Norby, M.M \& Ronning, R. R (2004). Cognitive psychology and instruction(4th ed) upper Saddle River, NJ: Pearson Education

Chambers Dictionary (2000). Great Britain: Chambers Harrap Publishers Ltd.

Design (5th edition). California: Wadsworth. edu/- mccay/apdm/selusing/selusing_d.htm Education, Inc.

Fincham, R \& Rhodes, P (2005). Principles of organizational behaviour (4th ed). New York: Gagne, R. M., Wager, W.W., Golas, K. C. \& Keller, J. M (2005). Principles of Instructional

Geen, S. K \& Gredler, M. E (2002). A review and analysis of constructivism for school-based practices. Review 31 (1) p. 53-70.

Gillies, Ashman \& Terwel (2007). The teacher's role in implementing cooperative learning in Irwin, Inc. Jersey: Pearson Merrill Prentice Hall.

Johnson, D. W., \& Johnson, R. T. (1991). Learning together and alone: Cooperative, competitive, and individualistic learning. Englewood Cliffs, NJ: Prentice Hall.

Journal of Education and Practice www.iiste.org ISSN 2222-1735 (Paper) ISSN 2222-Kauchak, D \& Engen P. (2008). Introduction to Teaching: Becoming a Professional. New March 2, 2009 from http://teacherworld.com/potdale.html.

Moore, K.D (2009). Effective Instructional Strategies. Los Angeles: SAGE O'daniel (1994)

O'Donnell, A. M., \& O'Kelly, J. (1994). Learning from peers: Beyond the rhetoric of positive results. Educational Psychology Review, 6, 321-349.

Ohan, D. U and Ugwu, E. J (2010). Factors which Predict Performance in Secondary School on Problem Solving Abilities among Senior Secondary School Physics Students in Oxford University Press.

Pastore, R. S. (2003). Creating, evaluating, and selecting instructional resources. Retrieved Physics. Advances in Applied Science Research, Vol. 1 (3), 255-258).

Pinto, Y (2012). The efficacy of homogeneous groups in enhancing individual learning

Pontecorvo, C. (1993) Social interaction in the acquisition of knowledge: Educational Psychology Review 5(3), p. 293-310. Press Southern Africa (Pty) Ltd.

Rue, L. W \& Byars, L. L (1993). Supervision: Key link to productivity (4th ed). USA: Richard D. Salomon (1989)

Salomon, G., \& Globerson, T. (1989). When teams do not function the way they ought to. International Journal of Educational Research, 13, 89-99.

Simple Harmonic Motion. Journal of Education and Practice www.iiste.org ISSN 2222-1735 (Paper) ISSN 2222288X (Online) Vol.4, No.25, 2013.

Slavin, Robert E (2009). Educational Psychology: Theory and Practice. New Jersey: Pearson States: John Wiley \& Sons, Inc. the classroom. New York: Springer

The Cone of Learning Experience (n.d). Retrieved January 23, 2009 from http://web.utk.

Vygotsky, L.S. (1962). Thought and Language. Cambridge, MA: MIT Press.

Weinberger, E. \& MacCombs, B.L. (2001). The impact of learner centered practice on the academic and nonacademic outcomes: American Educational research Association, Seattle, WA. 